\title{
Radionuclide contents and physico- chemical characterization of solid waste and effluent samples of some selected industries in the city of Lagos, Nigeria
}

\author{
N.N. JIBIRI ${ }^{1}$, G.O. ADEWUYI ${ }^{2}$
}

(Manuscript received 4 August 2007, accepted 23 November 2007)

ABSTRACT The radionuclide contents in waste products and physico-chemical characterization of effluent samples from some selected industries in the city of Lagos were carried out. The radioactivity concentration levels due to ${ }^{40} \mathrm{~K},{ }^{226} \mathrm{Ra}$ and ${ }^{228} \mathrm{Th}$ in the solid wastes were determined using gamma-ray spectrometry while physico-chemical determination of parameters were based on standard methods of measurements. The average radioactivity levels obtained was between $104 \pm 14 \mathrm{~Bq} \mathrm{~kg}^{-1}$ and $1276 \pm$ $31 \mathrm{~Bq} \mathrm{~kg}^{-1}$ for ${ }^{40} \mathrm{~K}, 86 \pm 18 \mathrm{~Bq} \mathrm{~kg}^{-1}$ and $122 \pm 23 \mathrm{~Bq} \mathrm{~kg}^{-1}$ for ${ }^{226} \mathrm{Ra}^{2}$ and while for ${ }^{228} \mathrm{Th}$ it ranged between $14 \pm 2 \mathrm{~Bq} \mathrm{~kg}^{-1}$ and $73 \pm 10 \mathrm{~Bq} \mathrm{~kg}{ }^{-1}$. No artificial radioactive elements were detected in any of the samples. The average outdoor effective dose rate due to gamma exposure from these waste materials in the city was calculated as $0.12 \mathrm{mSv}^{-1}$. This is far less than $1 \mathrm{mSv}^{-1}$ recommended limit for the member of the public by United Nations Scientific Committee on the Effects of Atomic Radiation (UNSCEAR). The pH of the effluent samples was slightly alkaline, while the electrical conductivity ranged between 275 and $455 \mu \mathrm{cm}^{-1}$ and total suspended solids ranged from 104 to $5616 \mathrm{mg} \mathrm{l}^{-1}$. All these ranges and those of biochemical and chemical oxygen demand values were all higher than the prescribed limits. Presence of heavy metals in the effluent samples was however lower than prescribed with the exception of iron.

Keywords: industrial waste products / physico-chemical parameters / radioactivity / natural radionuclides / Lagos

RÉSUMÉ Teneurs en radionucléides et caractérisation physico-chimique d'échantillons de déchets solides et d'effluent venant de quelques industries, sélectionnées dans la ville de Lagos, Nigéria.

Nous avons mené à bien la mesure des teneurs en radionucléides de déchets, ainsi que la caractérisation physico-chimique d'échantillons d'effluent venant de quelques industries sélectionnées dans la cité de Lagos. Nous avons déterminé par spectrométrie gamma les niveaux de concentration radioactive dus à ${ }^{40} \mathrm{~K},{ }^{226} \mathrm{Ra}$ et ${ }^{228} \mathrm{Th}$ dans les déchets solides; par contre, la détermination des paramètres physico-chimiques reposait sur les méthodes courantes de mesure. Les niveaux moyens de radioactivité obtenus se situent entre $104 \pm 14 \mathrm{~Bq} \mathrm{~kg}^{-1}$ et $1276 \pm 31 \mathrm{~Bq} \mathrm{~kg}^{-1}$ pour ${ }^{40} \mathrm{~K}$, entre $86 \pm$ $18 \mathrm{~Bq} \mathrm{~kg}^{-1}$ et $122 \pm 23 \mathrm{~Bq} \mathrm{~kg}^{-1}$ pour ${ }^{226} \mathrm{Ra}$, alors que, pour ${ }^{228} \mathrm{Th}$, le niveau va de $14 \pm 2 \mathrm{~Bq} \mathrm{~kg}^{-1}$ à $73 \pm 10 \mathrm{~Bq} \mathrm{~kg}^{-1}$. Nous n'avons détecté aucun élément radioactif artificiel, quel que soit l'échantillon. Le calcul montre que le débit de dose

Radiation and Health Physics Research Laboratory, Department of Physics, University of Ibadan, Nigeria.

Department of Chemistry, University of Ibadan, Ibadan, Nigeria. 


\begin{abstract}
efficace moyen, à l'air libre, dû à l'exposition gamma venant de ces déchets, est de $0,12 \mathrm{mSv} \mathrm{an}^{-1}$, dans la cité. Il est beaucoup plus bas que la limite de $1 \mathrm{mSv} \mathrm{an}^{-1}$ pour le public, recommandée par le Comité scientifique des nations unies sur les effets du rayonnement atomique (UNSCEAR). Le pH des échantillons d'effluent était légèrement alcalin ; la conductivité électrique se plaçait entre 275 et $455 \mu \mathrm{S} \mathrm{cm}^{-1}$; les suspensions solides se situaient entre 104 et $5616 \mathrm{mg} \mathrm{l}^{-1}$. Toutes ces plages de valeurs, comme celles des données biochimiques et chimiques de la demande en oxygène, se situaient au dessus des limites prescrites. Cependant, les teneurs des échantillons d'effluent en métaux lourds étaient inférieures aux valeurs prescrites, sauf dans le cas du fer.
\end{abstract}

\title{
1. Introduction
}

In developing countries, river pollution results from man's tendency to dilute and disperse wastes rather than to remove or treat at the source. This has made many rivers, waterways and streams in urban areas to be heavily polluted (Adewuyi et al., 2002). There is an increasing awareness to minimize the level of pollutants discharged into the environment (Jonnalagadda et al., 1991). During 1986-1993, Nigeria's manufacturing sector performance was observed to have improved sharply. This was reflected in the index of production of the industries by a factor of about 18 (Massey, 1992; Don-Pedro et al., 2004). These increased activities have undoubtedly benefited the Nigerian economy. It is rather of grave concern that over $80 \%$ of industries in the country discharge their solid waste, liquid and gaseous effluent into the environment without any prior treatment while just only $18 \%$, undertake rudimentary recycling prior to disposal. This is seen to pose a great threat to ecosystems and the health of its population because the current waste disposal methods include co-disposal of hazardous and municipal wastes in open, unlined dumps and open burning of solid wastes (Oyewo and Don-Pedro, 2003; Don-Pedro et al., 2004). Also, some of the by-products from these industries are of great concern because some are used for construction purposes, as feeds for domestic animals or as secondary raw materials for low scale or medium size industries. These wastes products may contain naturally occurring radionuclides in significant amount and may be a subject for external radiation exposure pathway to the population (Kolb and Schmier, 1978; Beretka and Mathew, 1985; Gibson et al., 1993; Ibrahim, 1999; Bruzzi et al., 2000).

Lagos metropolis is located in the far western part of Nigeria on latitude $6.45^{\circ} \mathrm{N}$ and longitude $3.47^{\circ} \mathrm{E}$. Till date, it is the economic nerve center of the country and the most populated city in the country (NPC, 2006). Furthermore, it has the highest concentration of manufacturing industries in the country with over 3000 industries (small, medium and large scale) and 12 industrial estates in the metropolis. This accounts for the magnitude of waste generated in the metropolis. The discharge of untreated or incompletely treated wastes will hasten the 
deterioration of receiving water bodies. Industrial pollution particularly the presence of organic and inorganic substances is the commonest and the most intractable (Connel, 1974). In terms of industrial pollution, Lagos lagoon absorbs 10000 cubic meters of industrial effluents per day including 30 metric tons of biological oxygen demand (Enville, 1998; LASEPA, 2001). The high water table and sandy soil of Lagos allows liquid effluents to leach easily into the ground water which is a major source of drinking water and concentration of specific pollutants may reach hazardous levels.

On the other hand, data on the radioactivity levels of the waste and by-products from industries in the country is still not known. Though, generally, data on radioactivity is quite sparse in the country. Despite constraints peculiar to our system, efforts are in progress towards enhancing radioactivity data in both the environment and environmental samples such as soil and water (Ferai and Sanni, 1992; Olomo et al., 1994; Jibiri and Farai, 1998; Farai and Jibiri, 2000; Farai and Ademola, 2001; Jibiri, 2001). The environmental radioactivity level of the city of Lagos has been established (Jibiri and Farai, 1998). Naturally occurring radionuclides (NORM) apart from soil and water are present in most materials, such as ores, paper, tiles, fertilizers, and almost in product materials of geologic origin. Besides, there are a number of industrial activities which may concentrate radionuclides particularly members of the ${ }^{232} \mathrm{Th}$ and ${ }^{238} \mathrm{U}$ decay series, in products and by-products or wastes (Abbady and El-Arabi, 2006; IAEA, 2006). A characteristic of NORM is that because of their wide distribution, they give rise to a very much larger radiological effect to the public compared with that caused by, for instance the nuclear industry (Mokobia et al., 2006). Also as technology develops so the waste streams from established industries may be causing new problems as they may be concentrating NORM in their waste to levels that are now exceeding the point at which regulatory concerns is required for radiation protection purposes (IAEA, 2006). This present study is aimed at determining the activity levels of the natural radionuclides and physico-chemical parameters in the different solid wastes and effluents samples respectively from some selected but representative industries in the metropolis of Lagos. This study was considered imperative because there is no data that presently exist on the radionuclide contents of waste products in the city.

\section{Experimental}

\subsection{Sampling and samples preparation}

Eight major groups of industries were identified and are representative of the different types of industry in the metropolis. These groups include; food, breweries, textiles, metal/aluminum, pharmaceutical, paper, paint and synthetic 
TABLE I

Activity levels of ${ }^{40} \mathrm{~K},{ }^{226} \mathrm{Ra}$ and ${ }^{228} \mathrm{Th}$ in the industrial waste products. Niveaux d'activité de ${ }^{40} \mathrm{~K},{ }^{226} \mathrm{Ra}$ et ${ }^{228} \mathrm{Th}$ dans les déchets industriels.

\begin{tabular}{|c|c|c|c|c|c|c|c|}
\hline \multirow[t]{3}{*}{ Industry } & \multirow{3}{*}{$\begin{array}{c}\text { Number of } \\
\text { samples }\end{array}$} & \multicolumn{6}{|c|}{ Activity concentration $\left(\mathrm{Bq} \mathrm{kg}^{-1}\right)$} \\
\hline & & \multicolumn{2}{|c|}{${ }^{40} \mathrm{~K}$} & \multicolumn{2}{|c|}{${ }^{226} \mathrm{Ra}$} & \multicolumn{2}{|c|}{${ }^{228} \mathrm{Th}$} \\
\hline & & Range & Mean & Range & Mean & Range & Mean \\
\hline Paint & 2 & $1024-1170$ & $1039 \pm 6$ & $121-130$ & $122 \pm 23$ & $72-74$ & $73 \pm 10$ \\
\hline Aluminum & 4 & $765-1460$ & $1236 \pm 11$ & $25-133$ & $83 \pm 20$ & $35-61$ & $51 \pm 11$ \\
\hline Synthetic & 6 & $625-2434$ & $1276 \pm 13$ & $41-188$ & $120 \pm 22$ & $11-32$ & $24 \pm 9$ \\
\hline Breweries & 4 & $1239-2036$ & $1483 \pm 12$ & $16-148$ & $86 \pm 18$ & $17-32$ & $23 \pm 7$ \\
\hline Food & 2 & $74-133$ & $104 \pm 14$ & \multicolumn{2}{|c|}{ BDL } & $14-13$ & $14 \pm 2$ \\
\hline Paper & 2 & $139-413$ & $276 \pm 24$ & $31-49$ & $40 \pm 15$ & $38-56$ & $24 \pm 7$ \\
\hline Textiles & - & - & - & - & - & - & - \\
\hline Pharmaceuticals & - & - & - & - & - & - & - \\
\hline
\end{tabular}

BDL - Below detection limit . The error terms represent gamma counting errors.

industries. Both waste and by-products from each category of industry were initially set out to be collected. However, due to unwillingness expressed by some of the management of the industries to release their generated wastes or by-product or both for analysis to great extent limited the number of samples collected for each group. Notwithstanding these constraints, the number of samples collected from each group was considered well enough for the objective of this study. With theses limitations solid wastes were only considered for radioactivity studies while the effluent wastes were for physico-chemical studies for those industries where collection was possible. The different industries covered are presented in Table I.

Samples were collected within the premises of the company into nylon bags and thereafter returned to the laboratory. At the laboratory samples after drying at room temperature until a constant weight was achieved, were crushed, sieved to pass $2 \mathrm{~mm}$ mesh and respective weights determined. They were transferred into an uncontaminated $60 \mathrm{~mm}$ height by $65 \mathrm{~mm}$ diameter containers and were sealed in these containers for a period of 28 days before counting. This was done in order to allow for radon and its short-lived progenies to reach secular radioactive equilibrium prior to gamma spectroscopy.

Effluent samples were collected from five factories; foods, paints, pharmaceuticals, synthetics and granite marble (Tab. II). The effluent samples were those ready to be discharged into the drains and the waterways. They were collected into clean plastic containers and were preserved with nitric acid. 
TABLE II

The mean and standard deviation of physico-chemical quality parameters of effluents from the different industries in the city.

Valeur moyenne et écart type de paramètres de qualité physico-chimiques, pour des effluents provenant de diverses industries, dans la cité.

\begin{tabular}{|c|c|c|c|c|c|}
\hline \multirow[t]{2}{*}{ Parameters } & \multicolumn{5}{|c|}{ Industrial Types } \\
\hline & Paint & Pharmaceutical & Synthetic & Food & Granite marble \\
\hline $\mathrm{PH}$ & $7.7 \pm 0.1$ & $7.5 \pm 0.1$ & $7.4 \pm 0.1$ & $8.6 \pm 0.2$ & $8.6 \pm 0.1$ \\
\hline $\begin{array}{l}\text { Conductivity } \\
\left(\mu \mathrm{S} \mathrm{cm}^{-1}\right)\end{array}$ & $275 \pm 17$ & $29 \pm 3$ & $283 \pm 3$ & $323 \pm 6$ & $455 \pm 1$ \\
\hline $\mathrm{BOD}\left(\mathrm{mg} \mathrm{l}^{-1}\right)$ & $135 \pm 4$ & $127 \pm 5$ & $124 \pm 3$ & $139 \pm 2$ & $138 \pm 3$ \\
\hline $\mathrm{COD}\left(\mathrm{mg} \mathrm{l}^{-1}\right)$ & $115 \pm 4$ & $113 \pm 2$ & $113 \pm 1$ & $113 \pm 2$ & $114 \pm 3$ \\
\hline $\operatorname{TSS}\left(\mathrm{mg} \mathrm{l}^{-1}\right)$ & $104 \pm 1$ & $162 \pm 1$ & $165 \pm 2$ & $5616 \pm 2$ & $936 \pm 1$ \\
\hline $\operatorname{DS}\left(\mathrm{mg} \mathrm{l}^{-1}\right)$ & $132 \pm 2$ & $136 \pm 1$ & $141 \pm 0.6$ & $222 \pm 2$ & $270 \pm 14$ \\
\hline Phosphate (mg l-1) & $0.05 \pm 0.01$ & $0.26 \pm 0.01$ & $0.31 \pm 0.01$ & $0.54 \pm 0.02$ & $0.55 \pm 0.01$ \\
\hline Chloride (mg l-1) & $36 \pm 4$ & $37 \pm 5$ & $41 \pm 8$ & $41 \pm 8$ & $38 \pm 4$ \\
\hline $\mathrm{Fe}(\mathrm{ppb})$ & $9.11 \pm 0.01$ & $3.47 \pm 0.01$ & $5.34 \pm 0.01$ & $7.01 \pm 0.01$ & $422 \pm 0.15$ \\
\hline $\mathrm{Cr}(\mathrm{ppb})$ & $0.08 \pm 0.01$ & $0.03 \pm 0.01$ & BDL & $0.01 \pm 0.008$ & $1.34 \pm 0.01$ \\
\hline $\mathrm{Zn}(\mathrm{ppb})$ & $5.40 \pm 0.05$ & BDL & $0.36 \pm 0.01$ & $0.24 \pm 0.09$ & $0.13 \pm 0.03$ \\
\hline $\mathrm{Cu}(\mathrm{ppb})$ & $4.7 \pm 0.01$ & BDL & $0.41 \pm 0.01$ & $0.01 \pm 0.008$ & $0.11 \pm 0.008$ \\
\hline
\end{tabular}

Thereafter they were transferred to the laboratory and kept in a refrigerator preset at $4{ }^{\circ} \mathrm{C}$ to inactivate bacteria growth.

\subsection{Gamma counting}

Radioactivity measurements were carried out using a lead-shielded $76 \mathrm{~mm} \times$ $76 \mathrm{~mm}$ NaI(TI) detector crystal (Model No. 802 series, Canberra Inc.) coupled to a Canberra Series 10 plus Multichannel Analyzer (MCA) (Model No. 1104) through a preamplifier. The detector had a resolution of about $8 \%$ at energy of $0.662 \mathrm{MeV}$. This was enough to distinguish the gamma ray energies being of interest in the present study. The choice of radionuclides to be detected as a reference was made based on the fact that the $\mathrm{NaI}(\mathrm{Tl})$ detector used in this study had a poor energy resolution. Hence the photons emitted by them would be sufficiently discriminated if their emission probability and their energy were high enough, and the surrounding background continuum low enough. Therefore, the activity concentration of ${ }^{214} \mathrm{Bi}$ (determined from its $1.765 \mathrm{MeV} \gamma$-ray peak) was chosen to provide an estimate of ${ }^{226} \mathrm{Ra}$ in the samples, while that of the daughter radionuclide ${ }^{208} \mathrm{Tl}$ (determined from its $2.615 \mathrm{MeV} \gamma$-ray peak) was chosen as an indicator of ${ }^{228} \mathrm{Th} .{ }^{40} \mathrm{~K}$ was determined by measuring the $1.460 \mathrm{MeV} \gamma$-rays 
emitted during the decay of ${ }^{40} \mathrm{~K}$. Finally, ${ }^{137} \mathrm{Cs}$ was also quantified (by looking for the $0.662 \mathrm{MeV} \gamma$-ray peak) as this isotope is an indicator for any potential environmental contamination due to nuclear accidents and weapon tests. The activity concentration level in each of the samples was calculated using the expression (Yener and Uysal, 1996; Farai and Ademola, 2001)

$$
C\left(\mathrm{~Bq} \mathrm{~kg}^{-1}\right)=\frac{C_{K}}{A_{K}} A
$$

where $C$ is the activity concentration of the radionuclide in the sample, $C_{K}$ is the activity concentration of the radionuclide in the standard reference sample $\left(\mathrm{Bq} \mathrm{kg}^{-1}\right)$, $A$ is the area count after background correction in the spectrum of the radionuclide in the sample and $A_{K}$ is the area count after background correction under the spectrum of the radionuclide in the standard reference sample. The standard reference sample used is traceable to source reference 48722-356 by Analytic Inc. Atlanta, Georgia. The lowest limits of detection (LLD) of the activities of the natural radionuclides in each sample were determined using environmental measurement laboratory procedure (USDOE, 1992) using the equation:

$$
D L\left(\mathrm{~Bq} \mathrm{~kg}^{-1}\right)=\frac{1.96\left[\frac{B}{T}+S D_{b}^{2}\right]^{\frac{1}{2}}}{k \varepsilon m}
$$

where $S D_{b}$ is the estimated standard error of the net background count rate in the peak, $T$ is the counting time (s), $\varepsilon$ is the counting efficiency (cps/Bq), $\mathrm{m}$ is the mass of the sample, $k$ is the factor that converts cps (counts per second) to $\mathrm{Bq}$ and 1.96 represents the $95 \%$ confidence level. The LLD values obtained were $17.31 \mathrm{~Bq} \mathrm{~kg}^{-1}$, 5.09 $\mathrm{Bq} \mathrm{kg}^{-1}$ and $5.06 \mathrm{~Bq} \mathrm{~kg}^{-1}$ for ${ }^{40} \mathrm{~K},{ }^{226} \mathrm{Ra}$ and ${ }^{228} \mathrm{Th}$ respectively. The activity values below LLD were considered to be below detection limit (BDL) of the detector.

\subsection{Physio-chemical measurements}

All reagents employed in this study were of analytical grade and were purchased from Aldrich Chemical Company and Fluka AG. The standard procedure by Ademoroti (1996) was employed in the Pysico-chemical measurements in this study. These methods were given in detail in our previous work (Adewuyi et al., 2002). The pH of the samples were measured using Kent Eil 7055 pH meter at in situ while the turbidity were measured using the bottle method, conductivity, biochemical oxygen demand, chemical oxygen demand, chloride and phosphate were similarly determined using the standard procedures Ademorati (1996). 


\section{Results and discussion}

The three radionuclides, ${ }^{40} \mathrm{~K},{ }^{226} \mathrm{Ra}$ and ${ }^{228} \mathrm{Th}$ have been detected and measured in all the samples while ${ }^{137} \mathrm{Cs}$ which was not detected in any of the samples. The activity concentration levels due to ${ }^{40} \mathrm{~K},{ }^{226} \mathrm{Ra}$ and ${ }^{228} \mathrm{Th}$ obtained are presented in Table I. Given the consideration made in the choice of peaks for analysis and the high shielded low-counting assembly used for the $\gamma$-counting, the combined uncertainties due to counting, background correction, and efficiency calibration was generally less than $25 \%$.

The concentration of the natural radionuclides as can be observed from Table I shows that the highest average concentration of ${ }^{40} \mathrm{~K}$ was $1483 \pm 12 \mathrm{~Bq} \mathrm{~kg}^{-1}$. This was obtained from the Breweries. The paint industries recorded highest concentration for ${ }^{226} \mathrm{Ra}$ of $122 \pm 23 \mathrm{~Bq} \mathrm{~kg}^{-1}$ and ${ }^{228} \mathrm{Th}$ of $73 \pm 10 \mathrm{~Bq} \mathrm{~kg}^{-1}$. The wastes product from the textile and pharmaceutical industries were mostly effluent and are channeled directly into the lagoons. More studies may need to be carried out on the activity levels of the aquatic species in the lagoons to ascertain the extent of industrial pollution. Since, no artificial radioactive substances were detected in any of the samples, it suffices to say, therefore that the waste and by products from these industries only exhibit natural activities. This is in agreement with previous study which reported that the environment of Lagos metropolis is uncontaminated of any artificial radioactive materials (Jibiri and Farai, 1998).

Furthermore, the activity concentrations of ${ }^{40} \mathrm{~K},{ }^{226} \mathrm{Ra}$ and ${ }^{228} \mathrm{Th}$ measured in each of the samples is only an indication of the levels of the radionuclides present and does not relate the effect of such level on bio-system especially when these wastes are dispersed into the environment and are potential sources of gamma radiation exposure to the population. The important quantity to assess when considering radiation risk to a bio-system is the absorbed dose rate. The absorbed dose rate, $D\left(\right.$ nGy $\left.^{-1}\right)$ in air at $1 \mathrm{~m}$ above the ground level due to the concentrations of the radionuclides in the samples is calculated using the equation (UNSCEAR, 2000):

$$
D=a C_{\mathrm{Ra}}+b C_{\mathrm{Th}}+c C_{\mathrm{K}}+d C_{\mathrm{Cs}}
$$

where $a$ is the dose rate per unit ${ }^{226} \mathrm{Ra}$ activity concentration $\left(4.27 \times 10^{-10} \mathrm{~Gy} \mathrm{~h}^{-1}\right.$ / $\left.\mathrm{Bq} \mathrm{kg}^{-1}\right), C_{\mathrm{U}}$ is the concentration of ${ }^{226} \mathrm{Ra}$ in the sample $\left(\mathrm{Bq} \mathrm{kg}^{-1}\right), b$ is the dose rate per unit ${ }^{228} \mathrm{Th}$ activity concentration $\left(6.62 \times 10^{-10} \mathrm{~Gy} \mathrm{~h}^{-1} / \mathrm{Bq} \mathrm{kg}^{-1}\right), C_{\mathrm{Th}}$ is the concentration of ${ }^{228} \mathrm{Th}$ in the sample $\left(\mathrm{Bq} \mathrm{kg}^{-1}\right), c$ is the dose rate per unit ${ }^{40} \mathrm{~K}$ activity concentration $\left(0.43 \times 10^{-10} \mathrm{~Gy} \mathrm{~h}^{-1} / \mathrm{Bq} \mathrm{kg}^{-1}\right), C_{\mathrm{K}}$ is the concentration of ${ }^{40} \mathrm{~K}$ in the sample $\left(\mathrm{Bq} \mathrm{kg}^{-1}\right), d$ is the dose rate per unit ${ }^{137} \mathrm{C}$ activity concentration $\left(0.30 \times 10^{-10} \mathrm{~Gy} \mathrm{~h}^{-1} / \mathrm{Bq} \mathrm{kg}^{-1}\right)$ and $C_{\mathrm{Cs}}$ is the concentration of ${ }^{137} \mathrm{Cs}$ in the sample 
$\left(\mathrm{Bq} \mathrm{kg}^{-1}\right)$. Since cesium-137 was not detected in any of the samples the last term in equation (3) was taken as zero. Using equation (3) and the average activity concentrations of the radionuclides in Table I, the average absorbed dose rate is calculated as $94 \mathrm{nGy} \mathrm{h}^{-1}$. The annual effective dose resulting from the absorbed dose rate values can be calculated using the following relation:

$$
E_{\text {air }}=T Q D_{\text {air }} \times 10^{-6} .
$$

Equation (4) can be summarized thus:

$$
E_{\text {air }}=T Q D_{\text {air }} \varepsilon
$$

where $E_{\text {air }}$ is the annual effective dose rate $\left(\mu \mathrm{Sv} \mathrm{y}^{-1}\right), T$ is time being $8766 \mathrm{~h} \mathrm{y}^{-1}, Q$ is the quotient of the effective dose rate and absorbed dose rate in air $\left(0.7 \mathrm{~Sv} \mathrm{~Gy}^{-1}\right)$, $\varepsilon$ is a factor converting nano $\left(10^{-9}\right)$ into micro $\left(10^{-6}\right)$ and $D_{\text {air }}$ is the absorbed dose rate in air $\left(\mathrm{nGy} \mathrm{h}^{-1}\right)$. Using equation (5) and the average absorbed dose rate of $94 \mathrm{nGy} \mathrm{h}^{-1}$ and taken into account the fact that the average person spends $20 \%$ of his/her time outdoors (UNSCEAR, 2000; Moeller and Sun, 2006), the average outdoor effective dose rate due to gamma exposure from these waste materials in the city would be $0.12 \mathrm{mSv}^{-1}$. This value is less than the recommended limit of $1 \mathrm{mSv} \mathrm{y}^{-1}$ for the members of the public (UNSCEAR, 2000; Abbadey and El-Arabi, 2006). From radiation protection point of view and for the purpose of this study, this dose value obtained is low and that harmful health effects are not likely to the population in the metropolis. However, results of our measurement have been taken to represent baseline values of these radioactive elements in these materials in the metropolis. From Table II, it can be observed that the effluents indicate high biological oxygen demand (BOD), chemical oxygen demand (COD), total TSS and DS values a revelation of high concentration of oxygen demanding pollutants which could be traced to the input of chemicals and organic based materials used for production. The values of TSS, DS, BOD and COD were all higher than the prescribed limit of $30 \mathrm{mg} \mathrm{l}^{-1}$ (FEPA, 1991). The hardness of the effluents was moderate in values $\left(35-39.7 \mathrm{mgCaCO}_{3}\right.$ ) as shown by the presence of calcium and phosphate and chloride that were within the set limits. The presence of metals in the effluents was also low with the exception of iron at the marble industry. These results indicate that to a lesser extent streams and waterways which receive these effluents are polluted. Steady and sustained increases in the parametric values above FEPA set limits clearly indicate a relationship between pollution levels and industrial activities. Although self purification of rivers or waterways where these effluents are discharged into may occur, measures for pre-effluent treatments are highly necessary. 


\section{Conclusion}

The natural activities of ${ }^{40} \mathrm{~K},{ }^{226} \mathrm{Ra}$ and ${ }^{228} \mathrm{Th}$ in industrial by-products and solid waste and physico-chemical parameters in effluent samples in some selected industries distributed within Lagos metropolis have been determined. No artificial radionuclide was detected in any of the samples analyzed. Majority of some of the physico-chemical parametric values were found to be higher than the prescribed standard limits. Although self purification of rivers or waterways where these effluents are discharged may occur, measures for pre-effluent treatments are highly necessary. The average outdoor gamma radiation dose value obtained due to the activity concentrations of the radionuclides in the samples is low and that harmful health effects are not likely to the population in the city.

\section{REFERENCES}

Abbadey A.G.E., El-Arabi A.M. (2006) Naturally occurring radioactive material from the Aluminum industry: A case study: The Egyptian Aluminum Company Nag Hammady, Egypt. J. Radiol. Protect. 20, 415-422.

Ademoroti C.M.A (1996) Standard method of measurements for water and effluent Samples, 1st edn. Foludex Press Ltd., Ibadan.

Adewuyi G.O., Jibiri N.N., Mabawonku A.O., Badmus, O.R. (2002) Effect of industrial discharges on the water quality of Soderu river in Ewekoro, South western Nigeria, UNIQWA Res. Chron. 4, 206-222.

Beretka J., Mathew P.J. (1985) Natural Radioactivity of Australian building materials, industrial wastes and By-products, Health Phys. 48, 87-95.

Bruzzi L., Baroni M., Mazzotti G., Mele R., Serena R. (2000) Radioactivity in raw materials and end products in the Italian ceramics industry, J. Environm. Radioact. 47, 157-170.

Connel D.W. (1974) Occurrence of Uranium in driking water in the USA, Health Phys. 50, 33-47.

Don-Pedro K.N., Oyewo E.O., Otitoloju A.A. (2004) Trend of heavy metal concentrations in Lagos lagoon ecosystem, Nigeria, West Afr. J. Appl. Ecol. 5, 103-114.

Enville (1998) Enville Environmental consultants, Environmental Audit report on needle punch factory, a division of Dunlop Nigeria Plc Oregun Ikeja, Nigeria.

Farai I.P., Ademola J.A (2001) Population dose due to Building Materials in Ibadan, Nigeria, Radiat. Prot. Dosim. 95, 69-73.

Farai I.P., Jibiri N.N. (2000) Baseline studies of terrestrial outdoor gamma dose rate levels in Nigeria, Radiat. Prot. Dosim. 88, 247-254.

Farai I.P., Sanni A.O. (1992) Year long variability of Rn-222 in a ground water sytem in Nigeria, $J$. Afr. Earth Sci. 15, 399-403.

FEPA (1991) Federal Environmental Protection Agency, National guidelines and Standards for industrial effluents, gaseous emissions and hazardous waste management in Nigeria, A Publication of the Federal Environmental Protection Agency of Nigeria.

Gibson J.A.B., Thompson I.M.G., Spiers F. (1993) A guide to the measurement of environmental gamma radiation. National Physical Laboratory, London.

IAEA (2006) International Atomic Energy Agency, Regulatory and management of approaches for the control of environmental residues containing naturally occurring radioactive material (NORM). Proceedings of a technical meeting held in Vienna, 6-10 December 2004. 
Ibrahim W. (1999) Natural activities of ${ }^{238} \mathrm{U},{ }^{232} \mathrm{Th}$ and ${ }^{40} \mathrm{~K}$ in building materials, J. Environm. Radioact. 45, 255-258.

Jibiri N.N. (2001) Assessment of health risk levels associated with terrestrial gamma radiation dose rates in Nigeria, Environm. Internat. 27, 21-26.

Jibiri N.N., Farai I.P. (1998) Assessment of dose rate and collective effective dose equivalent due to terrestrial $\gamma$-radiation in the city of Lagos, Nigeria, Radiat. Prot. Dosim. 75, 191-194.

Jonnalagadda S.B., Marthuthu A.S., Odipo R.W., Wandiga, S.O. (1991) River pollution in developing countries - A case study III- effect of industrial discharges on quality of Ngong river waters in Kenya, Bull. Chem. Soc. Ethiopia 5, 49-64.

LASEPA (2001) Lagos State Environmental Protection Agency, The Lagos Environment, Publ. LASEPA 2, 2-5.

Kolb W., Schmier H. (1978) Building materials induced radiation exposure of the population, Environm. Internat. 78, 69-75.

Massey P. (1992) Study of hazardous wastes management in Nigeria. WASTEC final report (a draft).

Moeller D.W., Sun L.S.C. (2006) Comparison of natural background dose rates for residents of the Amargosa Valley, NV, to those in Leadville, CO, and the states of Colorado and Nevada, Health Phys. 91, 338-353.

Mokobia C.E., Adebiyi F.M., Akpan I., Olise F.S., Tchnokossa P. (2006) Radioassy of prominent Nigerian Fossil fuels using gamma and TXRF spectroscopy, Fuel 85, 1811-1814.

NPC (2006) National Population Commission of Nigeria, Provisional census result of the Federal Republic of Nigeria.

Olomo J.B., Akinloye M.K., Balogun F.A. (1994) Distribution of gamma - emitting radionuclides in soils and water around nuclear research establishments, Ile-Ife Nigeria, Nucl. Instrum. Meth. Phys. Res. A 353, 553-557.

Oyewo E.O., Don-Pedro K.N. (2003) Estimated annual discharge rates of heavy metals from industrial sources around Lagos; a West African Coastal Metropolis, West Afr. J. Appl. Ecol. 4, 115-123.

UNSCEAR (2000) United Nations Scientific Committee on the Effects of Atomic Radiation. Sources and effects of ionizing radiation, Report to the General Assembly, New York, United Nations.

USDOE (1992) Environmental measurement laboratory procedure manual, 27th edn (revised) HASL300, Environmental measurement laboratory, United States Department of Energy, New York, p. 4.5.29.

Yener G., Uysal I. (1996) Low energy scintillation spectrometry for direct determination of ${ }^{232} \mathrm{U}$ and ${ }^{210} \mathrm{~Pb}$ in coal and ash samples, Appl. Rad. Isotope 47, 93-96. 